International Journal of Engineering \& Technology, 7 (4.3) (2018) $105-109$
International Journal of Engineering \& Technology
SPC
Website: www.sciencepubco.com/index.php/IJET
Research paper

\title{
Reduction of Construction Duration by Improving the Anti-Wear Properties of Power Fluids in Hydraulic Drives of Earth-Moving Machines
}

\author{
Serhii Voronin ${ }^{1}$, Dmytro Onopreychuk ${ }^{1 *}$, Volodymyr Stefanov ${ }^{1}$, Yevhenii Bashkatov ${ }^{2}$, \\ Vitalii Panchenko ${ }^{2}$ \\ ${ }^{1}$ Ukrainian State University of Railway Transport \\ ${ }^{2}$ National Academy of National Guard of Ukraine \\ *Corresponding author E-mail: dmytroonopriychuk@ukr.net
}

\begin{abstract}
The structure of reduction of construction duration which takes into account the effect of the electrostatic field on the power fluid of a hydrostatic power drive of earth-moving machines is considered. Experimental studies are also considered that suggest that the exposure of the power fluid to an electrostatic field leads to the intensified formation and increased thickness and bearing capacity of the lubricant film on the friction surfaces of the hydraulic drive. This causes the reduced wear rate of the components of a hydrostatic power drive. In particular, gaps in plunger pairs in the pump are reduced, which contributes to the increase of the coefficient of performance. As a result, the operating speed of the driven equipment increases, i.e., the work cycle duration is reduced, and hence the capacity of earth-moving machines increases and the duration of the preparatory earthwork, which is about a quarter of the total duration of all construction works in general, is reduced.
\end{abstract}

Keywords: capacity of earth-moving machines; electrostatic processing of power fluid; work duration.

\section{Introduction}

The initial stage of any construction, whether industrial or civil, is preparatory work. Part of such work is earthworks which includes excavation and removal of soil, digging pits and trenches, planning the construction site and more, depending on the facility being constructed. The preparatory work duration is about $20-25 \%$ of the total construction duration. It should be noted that such works are carried out using earth-moving machines (excavators, bulldozers, scrapers, etc.) and the total construction duration will directly depend on the technical performance indicators of the machinery, the main one being the capacity, which decreases in the course of operation of machines, which leads to the increased construction duration and cost. In this connection, the relevant issue arises oh improving the capacity of machines under sustained operation and reducing the intensity of capacity loss of earth-moving machines in general, which would enable to reduce the total construction duration and cost.

\section{Analysis of Recent Studies and Publications}

Technical performance indicators of earth-moving machines can be increased in comparison with the existing ones at the design and construction stage using new technical solutions and technologies [1-5]. Upgrade of the machines that are currently in service is reasonable under operating conditions [6]. For instance, works [7-10] provide for improvement of operating equipment for a particular type of work by changing the geometric design, cutting elements, the principle of operation, etc. Works [11-13] propose hybridization of earth-moving machines which enables increasing the number of work cycles without increase of energy consumption, but this approach reduces only the cost of work, not the duration. Modern earth-moving machines are known to have hydraulic drives, and their capacity depends entirely on the state of the hydraulic drive, therefore in works [14-16], the issues of increasing the coefficient of performance, improving the design of the elements, and facilitating the operability and energy saving capability of hydraulic drives are considered. However, it should be noted that the hydraulic oil (power fluid) plays a very important role in the hydraulic drive transmitting mechanical energy to the operating parts of machines and providing reliable lubrication and cooling of the friction surfaces of hydraulic machines. Electrostatic exposure is the most promising of all the methods for improving performance properties, in particular, the tribological properties of the power fluid, which include adding functional surface active agents, filtering, electric cleaning, and dispersing. This is confirmed in a series of works [17-19], which show significant improvement of anti-wear properties, intensification of the process of lubricant film formation, increase of the bearing capacity of the formed lubricant films, and explain the physical processes of the effect of the electrostatic field on power fluids (PF).

\section{The Basic Part of the Study}

\subsection{Purpose and Objectives of the Study}

The conducted analysis suggests that there are methods, algorithms and structural logical diagrams that show the effect of 
changing characteristics of the machine element on its technical and operational capacity, or the effect of the state of the power fluid on the element of the hydraulic drive with which it interacts with, but there is no structural logical diagram which would show the effect of changing anti-wearing properties of the power fluid of the hydraulic drive of the earth-moving machine by exposing it to the electrostatic field, on the change of construction duration. Thus, the purpose of the work is to determine the effect of exposure of the power fluid of the hydraulic drive of earth-moving machines to the electrostatic field on the construction duration.

\subsection{Theoretical Research}

The preparatory work duration depends on many factors, of which the capacity of earth-moving machines (EMM) is a decisive one. It is a basic, integral indicator and measure of production efficiency. Such a factor, in turn, definitely depends on a number of factors including the design and technical condition (EMM), the type of work being conducted, etc. If these factors are analyzed in general, then it can be stated that the use of EMM is reduced to two main integral indicators, namely: time and capacity. The average value of EMM capacity during execution of earthwork on land sites with different working conditions can be expressed as follows.

$$
P_{a}=\sum_{i=1}^{m} P_{i} \cdot J_{i}
$$

where $P_{i}$ - capacity of the machine during operation on site $i$; $J_{i}$ - probability of such work (specific weight of the works on the site).

Since EMM are equipped with the hydrostatic power drive and the cycle works duration is determined by the speed of operating elements in different operations as the works are executed, let us consider changes in capacity in the function of work cycle duration.

Earthworks duration is generally determined by the EMM capacity. If operating capacity, a single bucket excavator is taken as an example, is represented with an expression, we will obtain

$$
P_{o}=P_{t} \cdot K_{T}=\frac{q \cdot K_{f}}{K_{l} \cdot D_{c}} \cdot K_{T}
$$

where $P_{t}$ - technical performance, $\mathrm{m}^{3} / \mathrm{s} q$ - volume of bucket excavator, $m^{3} ; K_{f}$ - bucket filling coefficient; $K_{l}$ - soil conversion factor; $K_{T}$ - coefficient of transition from technical performance to operating capacity; $D_{c}$ - duration of the complete work cycle of the machine, sec.

Work cycle duration of EMM consists of the duration of particular operations which for a machine with a hydraulic drive (for an operation) can be expressed as

$$
t_{i}=\frac{L_{i} \cdot F_{i}}{Q_{t_{i}} \cdot \eta}
$$

where $L_{i}$ - average movement of the hydraulic cylinder piston (as an executive operating equipment) during the time of operation $i$ of the cycle, $m$;

$F_{i}$ - area of the piston of the pilot hydraulic cylinder, $\mathrm{m}^{2} ; Q_{t i}-$ average flow rate of the power fluid during the time of operation $i$ of the cycle, $\mathrm{m}^{3} / \mathrm{s} ; \eta$ - volumetric coefficient of performance of the pump.

Then the complete work cycle duration is represented by the dependence
$D_{c}=\sum_{i=1}^{n} \frac{L_{i} \cdot F_{i}}{Q_{t_{i}} \cdot \eta}$

where $n$ - number of individual operations in the complete work cycle of excavator.

Rated complete work cycle duration (if $\eta=\eta_{\mathrm{n}}$, i.e. volumetric coefficient of capacity of the pump has the rated value)

$D_{c n}=\sum_{i=1}^{n} \frac{L_{i} \cdot F_{i}}{Q_{t_{i}} \cdot \eta_{n}}$

It can be assumed that the ratio of current and rated operating capacity depends mainly on the ratio of the duration of the work cycles to the rated and current operating capacity

$$
\frac{P_{o}}{P_{o n}}=\frac{D_{c n}}{D_{c}},
$$

where $P_{o n}$ - rated operating capacity; $D_{c n}$ - duration of the complete work cycle, which corresponds to the rated operating capacity, c.

Using the expressions (4) (5) and (6), we can obtain

$\frac{P_{o}}{P_{o n}}=\frac{\eta}{\eta_{n}}$

In turn, the change in the volumetric coefficient of performance of the pump is determined by the wear intensity of the friction surfaces, that is, the gap width of the plunger pair of the pump. The gap width determines the leakage volume of the power fluid and the volumetric coefficient of performance of the pump. However, it should be taken into account that there is a certain lubricant film layer on the friction surfaces (plunger pairs), the increase of which results in the reduction of PF leakage volume, as well as the decreased wear intensity of the surfaces. The results can be achieved by exposure of PF to the electrostatic field. This is associated with the fact that the PF structure consists of base oil molecules, additives (surface-active agents (SAA)), products of wear and impurities. Due to the dipole moment, SAA form suparamolecular structures (micelles) in the power fluid. Due to the force field of the friction surface extending towards the normal to it inversely proportional to 3-4 degrees of distance, the micelles are destroyed, and the surfactants being in a monometric state are adsorbed on the surface forming a lubricant film. However, this is only possible provided the energy of the force field $E_{f}$ is greater than the binding energy of the molecules in the aggregate $E_{a}$, i.e. $E_{n}>E_{a}$. This is yet not always possible, therefore the additive cannot function properly. The force field of the friction surface is supported by the electrostatic field, which affects PF by destroying and rebuilding the micellar structures. This process leads to an increase in the number of SAA monomers in the volume of PF, as well as the probability of agglutination of molecules in the field, which leads to an increase in the number of oriented directional SAA aggregates and their denser packing in the surface layer, forming a polymolecular layer [17-20].

\subsection{Experimental Studies}

To confirm the above statements, a number of experimental studies have been conducted out aimed at determining the dependences of changing the lubricant film thickness and the wear rate of the friction pair on the electrostatic field intensity and its operation time.

The lubricant film thickness was measured using the "stack of balls" method by A.S. Akhmatov, which involves multiplication of the lubricant film thicknesses, that is, measuring the total thick- 
ness of $n$ lubricating layers, separated by $n+1$ thin mirror metallic plates. If the total thickness of the stack and $n+1$ of metal plates are known, lubricant film thickness is easy to calculate. Only metal balls are used instead of the plates in order to exclude the effect of the contamination particles on the results of measurements (Fig. $1)$.
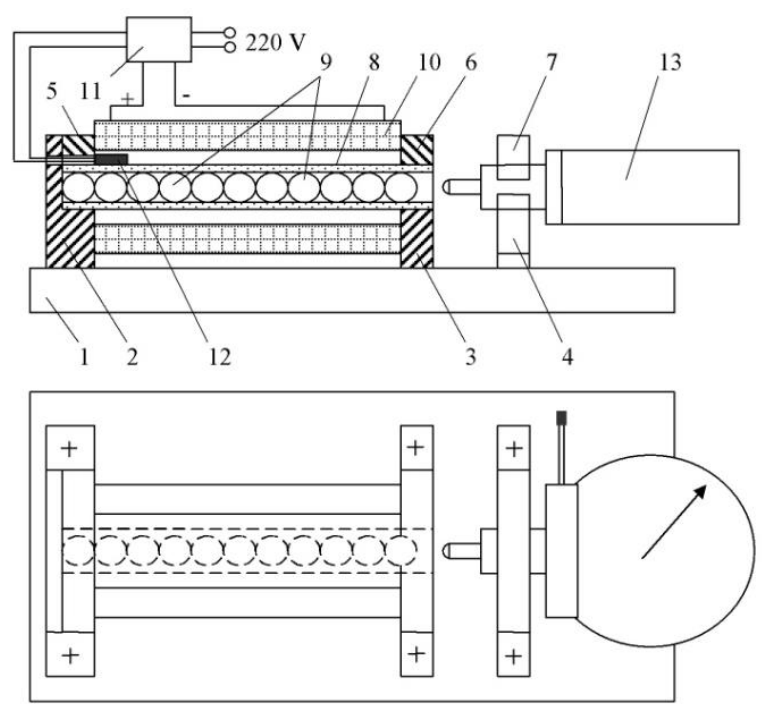

Fig. 1: Diagram of the device for measuring the lubricant film thickness: 1 - plate; 2, 3, 4- supports; 5, 6, 7- clamp covers; 8 - glass tube; 9 - balls; 10 - heater; 11 - temperature control; 12 - temperature sensor; 13 - micrometer.

The method of determining the lubricant film thickness is as follows. Thoroughly washed, degreased and dried balls 9 are placed in tube 8 , and then a stack of balls is loaded by force which is developed by the micrometric head of the indicator 13 . Then the indicator point is set to zero, and then the load on the stack is removed with the unloading device of the indicator. The balls are removed and moistened with the tested oil. The moistened balls are placed in tube 8 and another stack of balls is loaded, in a similar way. After the indicator point stops, the indications are read. The aggregate film thickness on the balls will be

$\sum h=2 \cdot(n+1) \cdot h$

where $n$-number of balls on the stack; $h_{i}$ - film thickness on one surface.

Based on the conditions of obtaining confident measuring results and expected film thickness, the minimum required number of balls was calculated using the expression

$$
n=\frac{e}{2 \cdot h_{i}}-1
$$

where $e$-precision of the metering device $\left(\mathrm{e}=1 \cdot 10^{-6} \mathrm{~m}\right) ; h_{i}-$ expected lubricating film thickness $\left(\mathrm{h}=0.1 \cdot 10^{-6} \mathrm{~m}\right)$.

Preliminary measurements were made to determine the minimum required repetition of experiments. The lubricating film thickness was measured ten times at a temperature of $\mathrm{PF} 20^{\circ} \mathrm{C}$ without electrostatic treatment.

The minimum necessary repetition of measurements is determined by inequality

$$
n_{\min } \geq \frac{\sigma^{2} \cdot t_{s}^{2}}{\Delta^{2} \cdot h_{a}^{2}}
$$

Where $\sigma$ - mean-square deviation of measurements; $t_{s}-$ table value of Student coefficient, $t_{s}=1.81$ with the result confidence
$P=0.9 ; \Delta$ - acceptable relative measurement error, $\Delta=0.5 ; h_{a}-$ arithmetic mean value of the measurement results [21].

Three time repetition was determined after preliminary measurements and calculations.

A hydraulic plant with the fluid flow velocity in the treatment unit $\mathrm{V}=6 \mathrm{~m} / \mathrm{s}=$ const, temperature $\mathrm{PF} \mathrm{t}_{\mathrm{pp}}=20^{\circ} \mathrm{C}=$ const was developed (Fig. 2) to expose PF to the electrostatic field.

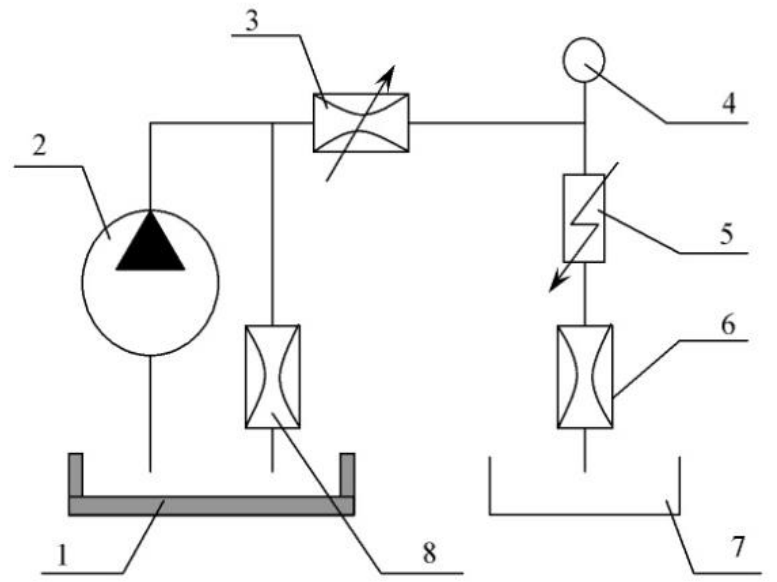

Fig. 2: Diagram of the laboratory hydraulic plant: 1 - thermostated tank with a heating element; 2 - vane-type pump; 3,6,8 - throttle; 4 - pressure gauge; 5 -PF treatment unit; 7 - container for treated PF.

The main obtained results of the experiment are shown in Fig. 3.

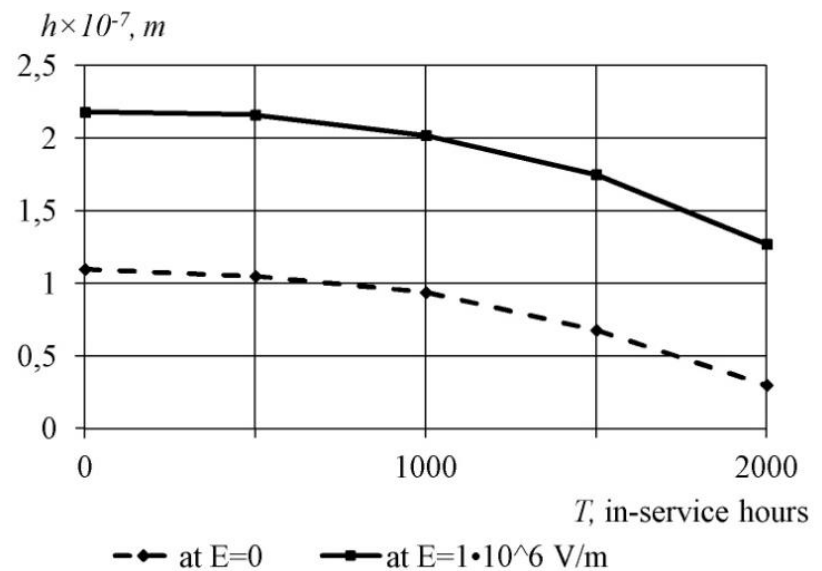

Fig. 3: Change of the lubricating film thickness depending on the inservice time after exposure of PF to the electrostatic field and without exposure: $E$ - electrostatic field intensity.

The obtained results allow concluding that when PF is in operation, the lubricant film thickness decreases both when PF is exposed to the filed and when it is not. However, the effect of the electrostatic field on PF increases the lubricant film thickness for new PFs twice, and for those in operation (2000 in-service hour) up to 3 times at the electrostatic field intensity of $1 \times 10^{6} \mathrm{~V} / \mathrm{m}$. This parameter of the electrostatic field intensity is rational according to the lubricant film thickness criterion.

In the experimental wear test, the friction pair with the surface contact in the "barrel-roller" plane which is implemented in the plunger pairs of the pump was accepted. Wear tests were conducted with SMT-1 friction machine. In Fig. 4, the diagram and the overall view of the laboratory unit for friction wear testing using the friction machine is shown. 


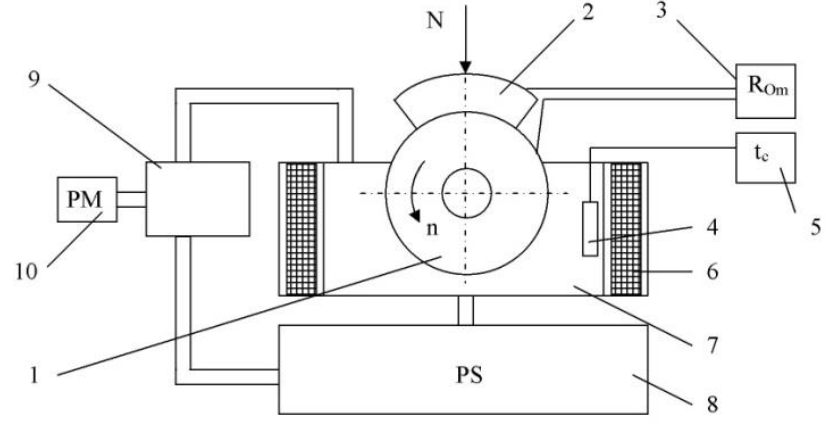

Fig. 4: Diagram of the laboratory wear testing unit for the "barrel-roller" friction pair with SMT-1 friction machine: 1 - roller; 2 - barrel; 3 - Ohmmeter; 4 - thermal gauge; 5 - temperature control; 6 - heating element; 7 container; 8 - pumping station; 9 - treatment device for PF; 10 - power module.

The materials of the samples (a roller and a barrel) were selected in accordance with the materials of the plunger pair which are used in the pumps of 224.20, 313.3.55 series. According to the analysis of the designs, the material of the barrel was Br.012 bronze, while the material of the roller was $38 \mathrm{H} 2 \mathrm{MYuA}$ steel. The surface roughness of the barrel and the roller were selected in accordance with the design documents for the above pump, the necessary actual contact area was thus ensured.

The samples were manufactures and prepared to testing, and the method of wear determination was used according to GOST $23.224-86$.

Testing was conducted with the fluid flow velocity in the device 6 $\mathrm{m} / \mathrm{s}$, temperature of the power fluid in the tank of the pumping station $70^{\circ} \mathrm{C}$, contact pressure $8 \mathrm{MPa}$, and linear sliding speed of the roller $0.3 \mathrm{~m} / \mathrm{s}$.

The pressure value in contact and the sliding speed of the roller ensure the limit lubrication of the friction pair throughout the test range.

The required repetition of experiments was determined by expression (10), only the acceptable relative measurement error was $\Delta=0.1$.

The obtained results of the study (Fig. 5) show that the longer the service life of the power fluid is, the faster the wear rate increases non-linearly for both the non-treated and treated power fluid.

Using electrostatic exposure of the power fluid results in decreased wear rate of the friction pairs (plunger pairs) up to 4 times for the fluid in the delivery condition and up to 3 times for the fluid which was in service of the hydraulic system of the machine for 2000 hours.

The rational value of the electrostatic field parameter depending on the in-service time is $1 \times 10^{6} \mathrm{~V} / \mathrm{m}$.

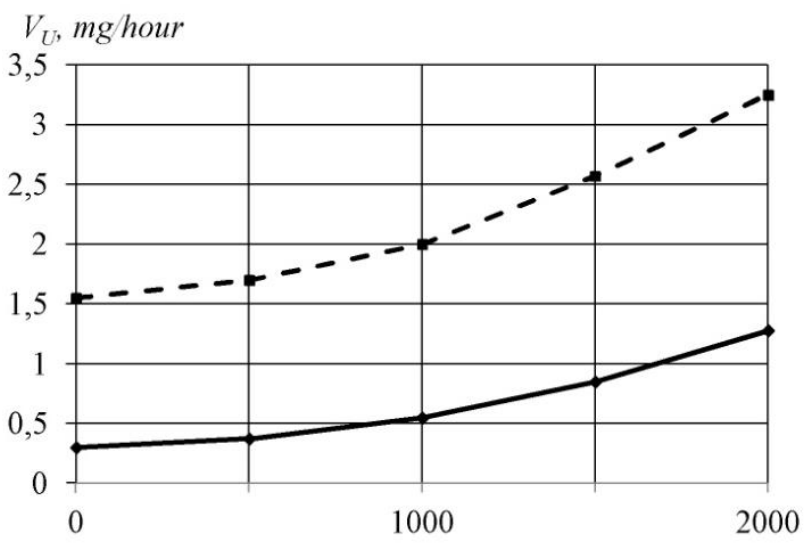

$T$, in-service hours

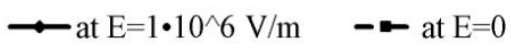

Fig. 5: Change in time of the wear rate of the barrel after exposure of PF to the electrostatic field and without exposure: $E$ - electrostatic field intensity.

\subsection{Results of the Calculation and Discussion}

Thus, the obtained results of experimental studies conducted to the determine the effect of the electrostatic field on the lubricating film thickness and the effect of the electrostatic field on the wear rate of the "barrel-roller" friction pair at different in-service times of PF allows asserting that the law of the change in the volumetric coefficient of performance of the pump in time can be displayed using the graph (Fig. 6).

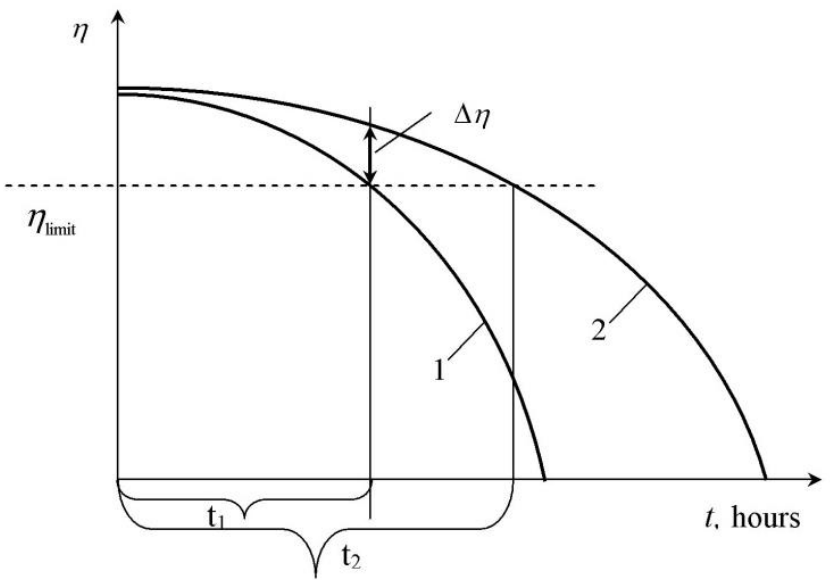

Fig. 6: Change of the intensity of loss of pump efficiency: 1 - when nontreated power fluid is used; $2-$ when the power fluid is exposed to the electrostatic field

On the basis of allowances of the graph (Fig. 6) and dependence (7) the operating capacity can be determined

$P_{o}=P_{o n} \cdot \frac{\eta}{\eta_{n}}$

According to the results of experimental studies (Figures 3, 5) and dependence (11), we will plot a structural logical diagram of the effect of exposure of the powered fluid of the hydraulic drive of earth-moving machines to the electrostatic field on the construction duration of (Fig. 7).

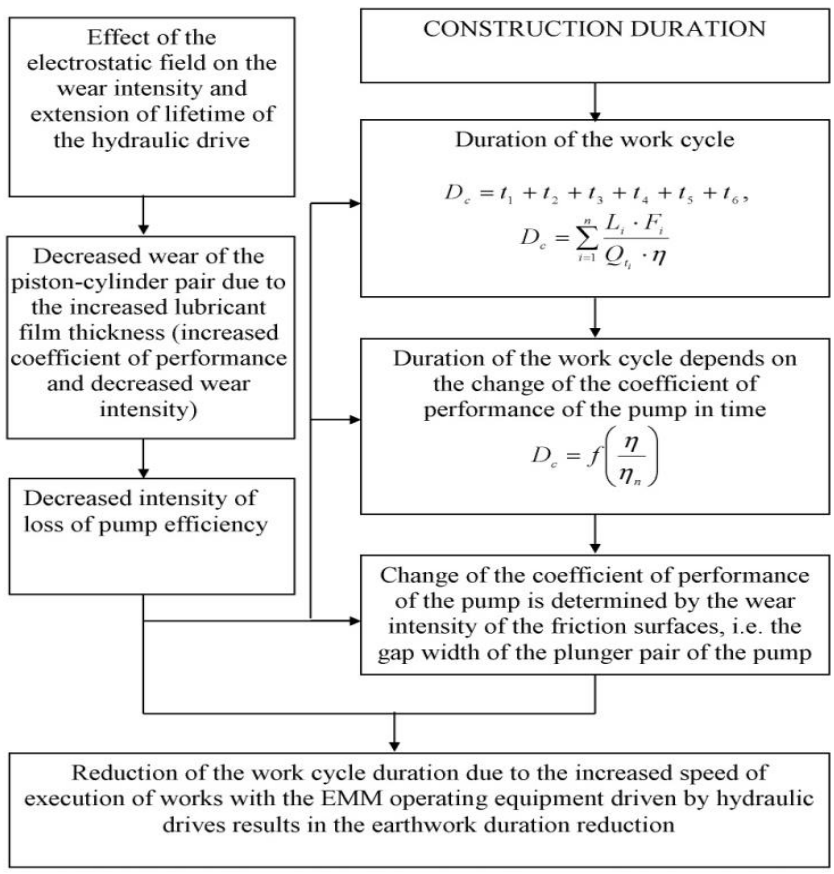

Fig. 7: Structural logical diagram of the reduction of the duration of construction work

Effect of the electrostatic field on the power fluid results in reduced gap width in plunger pairs in the pump due to the increased lubricant film thickness, i.e. increased coefficient of performance, 
leading to the reduced work cycle duration, and accordingly, increased capacity of the earth-moving machines, which in turn reduces the construction duration.

\section{Conclusion}

The main type of the preparatory work is earthwork, the duration of which depends on the EMM performance. Since these machines are equipped with hydraulic drives, the capacity depends on the state of the hydraulic drive which deteriorates in the course of operating life of the machine. Analysis of the studies has shown that the exposure of the power fluid to the electrostatic field is the most promising way of upgrading EMM during their operation in order to increase capacity.

The effect of the electrostatic field on the power fluid leads to the intensified formation and increased lubricating film thickness in the plunger pairs of the pump. The maximum value of the lubricant film thickness is achieved when the field intensity is $1 \times 10^{6}$ $\mathrm{V} / \mathrm{m}$. The same field intensity value provides for a decreased wear rate of the friction pairs (plunger pairs of the pump) up to 4 times with the new power liquid and up to 3 times for a fluid with a service life of 2000 in-service hours.

The structural and logical diagram of the effect of electrostatic exposure of the power fluid on the construction duration is plotted, which allows to calculate the construction duration at different life cycles of earth-moving machines taking into account the effect of the electrostatic field on the power fluid.

\section{References}

[1] L.Ie. Pelevin, I.I. Nazarenko, Ye.V. Horbatiuk Stvorennia osnov teorii peredachi enerhii robochymy ridynamy v dynamichnykh systemakh pryvodiv mashyn, Ahrar Media Hrup, Kyiv (2014), 144 p.

[2] V.M. Smirnov, V.P. Holovan, O.Iu. Volters Rozrobka vysokoefektyvnoho burylnoho obladnannia dlia stvorennia sverdlovyn pid stovpchasti opory budivelnykh sporud v skladnykh heolohichnykh umovakh, Komprynt, Kyiv (2016), $280 \mathrm{p}$

[3] A.V. Fomin O.O. Kosteniuk, O.A. Teteriatnyk, I.M. Bokov-nia, Parametry robochoho protsesu aktyvnykh gruntorozrob-nykh robochykh orhaniv. Hirnychi, budivelni, dorozhni ta melioratyvni mashyny. Vseukrainskyi zbirnyk naukovykh prats Kyivskoho Natsionalnoho universytetu budivnytstva $i$ arkhitektur, Vol.73, (2009), pp. 78-81.

[4] M.K Sukach, V.A. Yahodynets Ekskavator zi zmishchenoiu vissiu kopannia Hirnychi, budivelni, dorozhni ta melioratyvni mashyny. Vseukrainskyi zbirnyk naukovykh prats Kyivskoho Natsionalnoho universytetu budivnytstva i arkhitektur, Vol.73, (2009), pp. 67-70.

[5] M.P. Remarchuk, A.O. Zadorozhnii, Ya.V. Chmuzh Metodolohiia proektuvannia hidravlichnoho pryvodu na osnovi zastosuvannia systemnoho analizu, Skhidno-yevropeiskyi zhurnal peredovykh tekhnolohii, Vol. 2 №7(86) (2017), pp. 42-50

[6] L.A. Khmara, M.P. Kolisnyk, V.P. Stanevskyi Modernizatsiia ta pidvyshchennia produktyvnosti budivelnykh mashyn: monohrafiia, Budivelnyk, Kyiv, (1992), $152 \mathrm{p}$

[7] L.A. Khmara, O.O. Dakhno Teleskopichne roboche obladnannia hidravlichnoho ekskavatora, otsinka yoho efektyvnosti ta vyznachennia obiemu kopannia gruntu, Stroytelstvo, materyalovedenye, mashynostroenye, № 66.4.2. (2012), pp. 29-37

[8] V.F. Demishkan, M.P. Remarchuk, M.M. Burmaka Vyzna-chennia ekonomichnoho efektu za rakhunok udoskonalennia nozhiv robochoho obladnannia mashyn dlia zemlianykh robit, Naukovyi visnyk budivnytstva, Vol. 55, (2009), pp. 202-207.

[9] L.A. Khmara, S.V. Shatov Doslidzhennia rozpushuvachiv iz dekilkoma zubtsiamy, roztashovanymy na riznykh rivniakh, Visnyk Kharkivskoho natsionalnoho avtomobilno-dorozhnoho universytetu, Vol. 73, (2016), pp. 150 - 156.

[10] V.N. Kuznetsova, R.A. Martiukov Eksperymentalnye yssledovanyia nahruzhenyia zuba rykhlytelei pry razrabotke merzlykh hruntov, Stroytelnye y dorozhnye mashyny. №4 (2006), pp. 35-37

[11] L.A. Khmara A.P. Kholodov Hybrydnyi pryvod mashyn dlia zemlianykh rabot - put $\mathrm{k}$ snyzhenyiu enerhoemkosty rabochykh protsessov, Stroytelstvo. Materyalovedenye. Mashynostroenye. №88, (2016), pp. 108-116.
[12] L.A. Khmara, A.P. Kholodov Raspredelenye sylovykh potokov v rabochem tsykle zemleroino-transportnykh mashyn, osnashchennykh hydroakkumulyruiushchei systemoi Visnyk Kharkivskoho natsionalnoho avtomobilno-dorozhnoho universytetu, Vol. 57. (2012), pp. 166-173.

[13] Volvo driving fuel efficiency, Volvo construction equipment magazine $01 / 2010$ issue $34-22 \mathrm{p}$.

[14] N.P. Remarchuk Modernyzatsyia nasosnoi ustanovky hydravlycheskoho эkskavatora NOBAS UB 1232 - 1 «BAUKEMA», Visnyk Kharkivskoho natsionalnoho tekhni-chnoho universytetu silskoho hospodarstva imeni Petra Vasylenka, Vol. 111. (2011), pp. 23-31.

[15] V.Ie. Panarin, M.Ie. Svavilnyi, A.I. Khominych, M.V. Kindrachuk A.O. Korniienko Stvorennia dyfuziinoho barieru na mizhfaznii poverkhni kompozytsiinykh pokryttiv, zmtsnenykh vuhletsevymy nanotrubkamy, Zhurnal nano- ta elektronnoi fizyky, Tom 9 №6 (2017), pp. 06023-1 - 06023-5.

[16] M.P. Remarchuk Enerhozberezhennia v hidrosystemakh upravlinnia robochym obladnanniam mashyn dlia zemlianykh robit, Visnyk Kharkivskoho natsionalnoho tekhnichnoho uni-versytetu silskoho hospodarstva im. P. Vasylenka, Vol. 147. (2014), pp. 139-144.

[17] E.N. Lysykov, V.B. Kosolapov, S.V. Voronyn Nadmoleku-liarnye struktury zhydkykh smazochnykh sred y ykh vlyianye na yznos tekhnycheskykh system EDENA, Kharkov, (2009), 274 p.

[18] S.V. Voronyn, A.V. Dunaev Vlyianye elektrycheskoho y mahnytnoho polia na mekhanyzm deistvyia prysadok $\mathrm{k}$ maslam, Trenye y yznos: mezhdunarodnyi nauchnyi zhurnal, Vol.36, № 1, (2015), pp. 41-49.

[19] E.N. Lysykov, S.V. Voronyn Yntensyfykatsyia protsessa adsorbtsyy molekul prysadky na poverkhnostiakh trenyia tekhnycheskykh system, Naukovo-tekhnichnyi zhurnal «Problemy tertia ta znoshuvannia», Vol. 57. (2012), pp. 273-279.

[20] S. Voronin, Development of tribophysical foundations of lubricity of liquiderystal additives to base oil, EasternEuropean Journal of Enterprise Technologies, Vol.3, No.7, (2015), pp.53-57.

[21] S. Voronin, P. Konovalov, D.Onopreychuk, V. Stefanov, V. Pashchenko, H. Radionov, V. Temnikov, A. Onoprienko A study of the effect of electrostatic processing on performance characteristics of axle oil Eastern-European Journal of Enterprise Technologies, Vol. 1, № 1(91), (2018), pp.4-12 